\title{
Value Orientation among Tribal Future Teachers of B.Ed. Programme: Need for Curricular Interventions
}

\author{
Rajendra Prasad Dasari
}

Department of Education, Kakatiya University, India

Copyright $(2016$ by authors, all rights reserved. Authors agree that this article remains permanently open access under the terms of the Creative Commons Attribution License 4.0 International License

\begin{abstract}
Schools play a vital role in inculcation of values and development of values. It has become, of late, the central concern of teacher education. Teacher education programmes are the effective modes of transmission of values having a direct impact on the school education. A College of Teacher Education was established at Badrachalam exclusively for tribal population in the State of Telangana under Integral Tribal Development Authority (ITDA). In this institution only tribes of different communities are given the opportunity of pursuing B.Ed. Programme. Tribal habitat, culture and living styles are different because they live in deep forest in hamlets away from the mainstream of the society and their value system needs attention for their emancipation in social development. In this article, the value system and value preferences of tribal future teachers of the B. Ed. Programme are discussed to provide guidelines for curricular interventions for quality tribal teacher education.
\end{abstract}

Keywords Tribal Future Teachers, Values, B. Ed. Programme

\section{Introduction}

Thought is the root cause of every action. At impressionable age, school children are quick to grasp. Teacher plays a vital role in creation of values among the school children. Upanishads (holy scriptures of Hindu religion) have long ago given the concept of VasudhaivaKutumbakam (all humanity is one family). Science is continuously predicting natural laws and technological applications are taking place in every field to establish a better society. Different Commissions and Committees and National Policies on Education stressed the need of value education. Institutions like Santiniketan, Ramakrishna Mission, Pondicherry Ashram of Sri Aurobindo and Krishnamurthy Foundation are providing education based on values. The Forty-sixth International Conference on education held at Geneva on the theme of 'learning to live together' made conclusions and proposals for action related to the teacher. These are: a) improving the education of the teacher so that they can better develop pupils' behavior and values of solidarity and tolerance b) prepare them to prevent and resolve conflicts peacefully and to respect cultural diversity c) changing the relationship between teacher and pupil to respond to the evolution of society. Hence, it placed great responsibility on the teacher with a vision of protection of the universe, nature and society by way of educating the future generations [1].

The Fifth Survey of Educational Research conducted by National Council of Educational Research and Training [2, 3] identified values as one of the important areas of research and the survey cited studies under 'Moral, art and aesthetic education'. Of the thirty one studies in moral education, one is related to value preference and the other related to value clarification, were of teacher trainees. The Sixth Survey of Educational Research [4] stated that there was a marked decline of interest in value research and the area of value measurement had remained a neglected area as far as Indian Research is concerned. The Survey has identified eight studies related to values of teachers and student teachers. The Eighty First Parliamentary Committee Report [5] had, nevertheless, in recent years, elaborately dwelt upon the nature of desired value education programmes and the need to develop strategies for implementation of these programmes. Longstreth [6] found that almost all teachers believed that the schools should be concerned with values, but they were divided on the issue of ways of inculcation of values. Most of the teachers did not believe in planning value-education, and rather preferred giving examples for values.

Kakkar's [7] study on the values among teacher trainees and college teachers reported significant differences on economic, aesthetic and social values and no significant differences on theoretical, political and religious values among teacher trainees and teacher educators. Usha Sri's [8] study on 'Restructuring Teacher Education for Value Orientation' suggested a syllabus for value education paper for the B.Ed. course comprising of twelve units covering all aspects of value education. Singh and Singh [9] conducted 
an experimental study using Value Clarification Strategies (VCS) in comparison with traditional method to teach values to B.Ed. students and concluded that VCS are more effective than conventional methods for teaching the value of 'dedication to teaching profession', 'cooperation', 'nationalism' and inculcation of scientific outlook. Mark Winterbottom study [10] used cluster analysis to examine groupings of trainee teachers against dimensions underpinning their values and practice in relation to assessment. Cluster analysis of factor scores from varimax rotated principal components analysis revealed four clusters of trainees in relation to their practice responses, and two clusters in relation to values responses. Membership of clusters was found to be associated with membership of particular subject disciplines. Bhushan's [11] study findings are: male and female prospective teachers uniformly assigned highest importance to self control, obedience and honesty. Female prospective teachers ranked forgiveness, ambitions, helpfulness, and lovingness higher than their male counterparts, while male teachers ranked logic, courage, capability, responsibility, imagination and independence higher than female counterparts. The highest importance was given to self-control and honesty and lowest importance to logic and capability by female prospective teachers. Highest importance to intellectuality and lowest to broadmindedness was given by male prospective teachers. Nayyar [12] study revealed that the future teachers' most important values are justice, discipline and honesty. Singh [13] identified a significant relationship between intelligence and value orientation gain for cooperation, dedication, perseverance, scientific outlook and rationalization among B.Ed. students.

Rajendra Prasad [14] found more similarities among the male and female in-service teachers of B.Ed. (distance education) programme with regard to more preferred terminal values but more preferred instrumental values of them were found to be totally different. In another study, Rajendra Prasad [15] found the more preferred terminal values of M.Ed. students were a world at peace, equality and wisdom and the more preferred instrumental values were ambition, helpful and broadminded. Escobar, Ortloff, L. M. and Ortloff, W, G. [16] study revealed that both professors and students of teacher education had given highest preference to the terminal values, equality and exiting life. Professors ranked the value "A world at peace" a more preferred one. The students had given least importance to the same. The more preferred instrumental values of professors were capability and helpfulness while that of students are independence and politeness. Aparna Mitra [17] stated that despite the heterogeneity found among the different tribes, they all display some common characteristics in their family and social values. Steven Locke and Lorinda Lindley [18] collected data from American Indian pre-service teachers. Their study revealed that the course replicated and reproduced dominant cultural values and knowledge of the state university and was insensitive to American Indian history, values, and pedagogy. The review of studies shows that the value system of B.Ed. students of tribal community need some attention as many of them go back to their native places to serve the educational needs of tribal community and influence the value system of tribes. Zheng [19] stated that pre-service teacher beliefs are the focus of change in the process of education and teacher education should be oriented towards the formation of beliefs.

The present study is an attempt to look into value system and value preferences of the tribal future teachers of B.Ed. programme. For the purpose, student-teachers undergoing B. Ed. Programme in the teacher education college at Badrachalam established by Integrated Tribal Development Authority (ITDA) especially for tribes had been selected.

\section{Study Procedure}

The study adopted Rokeach Value Survey (RVS) with terminal and instrumental values, each with 12 set of values mostly related to teaching profession, looking into the common judgment of the experts. Each value was accompanied by a short descriptive phrase in parenthesis. The values in both sets were arranged in alphabetical order. Terminal values were presented before the instrumental values. The responses were given by the future teachers in order of their own preferences guiding their life, 1 to 12 against each value for each set of values. The reliability coefficient of 0.76 for terminal values and 0.69 for instrumental values, had established substantial reliability (The range of $0.60-0.80$ indicates substantial reliability) of the tool. The validity coefficient for terminal values is 0.919175 and for instrumental values is 0.787594 , indicate the acceptable validity. The sample included 47 future teachers completing their B.Ed. programme, selected randomly. It included 21 male and 26 female of them 21 belonged to koya, 12 lambada and 14 other primitive tribes. 10 were married and 37 unmarried in the sample. It also included 32 and 15 future teachers belonging to science/mathematics and social studies methodology respectively.

\section{Results}

The data collected by administering the tool is presented in the tables 1 and 2. Normalized-rank order method is used in which the sums of the rank values for various values would give the best indications of ranking. For different numbers ranked (n), corresponding $\mathrm{C}$-scale values are given in the table. Sum of the product of total preferences and $\mathrm{C}$ values calculated is represented by $\sum f_{j i} C$. The means of $\sum f_{j i} C$ are computed, known as response value $R_{j}$. Based on the means of 12 values the rank order is given for each value. Highest mean value is given rank 1 and the lowest one is given rank 12 in the tables 1 and 2 for terminal and instrumental values.

Table 1 (Appendix-1) reveals the rank order of terminal 
values of the tribal future teachers. The order of preference of values system of the future teachers for terminal values is observed as follows:

1. A comfortable life (A Prosperous life)

2. True Friendship (Close companionship)

3. Pleasure (An enjoyable, leisurely life)

4. Wisdom (A mature understanding of life)

5. Freedom (Independence, free choice)

6. An exiting life (A stimulating, active life)

7. Happiness (Contentedness)

8. Equality (Brotherhood, equal opportunity for all)

9. Social Recognition (Respect, admiration)

10. Self-respect (Self esteem)

11. Family security (Taking care of loved ones)

12. A world at peace (Free of war and conflict)

Table 2 reveals (Appendix-2) the rank order of instrumental values of the future teachers. The order of preference of values system of the future teachers for instrumental values is observed as follows:

1. Polite (Courteous, well-mannered)

2. Obedient (Dutiful, respectful)

3. Honest (Sincere, truthful)

4. Capable (Competent, effective)

5. Independent (Self-reliant, self-sufficient)

6. Helpful (Working for the welfare of others)

7. Broad-minded (Open minded)

8. Responsible (Dependable, reliable)

9. Ambitious (Hard working, aspiring)

10. Forgiving (Willing to pardon others)

11. Intellectual (Intelligent, reflective)

12. Courageous (Standing up for beliefs)

The more preferred and less preferred terminal and instrumental values of the future teachers are represented in table 3 (Appendix-3).

The more preferred terminal values of the future teachers are in the order of:

1. A comfortable life (A Prosperous life)

2. True Friendship (Close companionship)

3. Pleasure (An enjoyable, leisurely life)

The less preferred terminal values of the future teachers are in the order of:

1. A world at peace (Free of war and conflict)

2. Family security (Taking care of loved ones)

3. Self-respect (Self esteem)

The more preferred instrumental values of the future teachers are in the order of:

1. Polite (Courteous, well-mannered)

2. Obedient (Dutiful, respectful)

\section{Honest (Sincere, truthful)}

The less preferred instrumental values of the future teachers are in the order of:

1. Courageous (Standing up for beliefs)

2. Intellectual (Intelligent, reflective)

3. Forgiving (Willing to pardon others)

\section{Discussion}

The tribal future teachers have given highest preference to a comfortable life followed by true friendship and pleasure. This shows that these future teachers' values are oriented towards comfortable life and true friendship leading to pleasure. They least preferred a world at peace followed by family security and self respect. Their values of end state of existence are found to be much self oriented. Politeness is the most preferred instrumental value of the tribal future teachers followed by obedience and honesty. This shows that their mode of conduct is much oriented towards politeness, obedience and honesty, indicating that their instinct of tribal character is intact in the teacher education programme. They least preferred the value of courageousness followed by intellectuality and forgiveness. This shows that their mode of conduct is less oriented towards courageousness, intellectuality and forgiving nature.

\section{Conclusions}

The study revealed that the tribal future teachers' values are oriented towards a comfortable life with pleasure and true friendship rather than social dimensions of freedom, equality and peace even though the Indian constitution is based on a democratic and socialistic set up. Hence, the curricular interventions are of greater significance to inculcate these values in the tribal future teachers. However, their mode of conduct is more oriented towards politeness, obedience and honesty, indicating their basic tribal character is intact. Tribal future teachers' least preference towards courageousness, intellectuality and forgiving nature needs some concern. To inculcate these values among tribal future teachers curriculum should provide space to encourage them to participate in independent and group based problem solving activities in the practical component offered in the teacher education programme so that they become not only self-confident, courageous and intellectual but also develop tolerance, forgiving nature and learn to live with other tribes and social groups as well. 


\section{Appendix-1}

Table 1. Rank Orders of Terminal Values of Tribal Future Teachers of B.Ed. Programme

\begin{tabular}{|c|c|c|c|c|c|}
\hline $\begin{array}{l}\text { Sl. } \\
\text { No. }\end{array}$ & Terminal Values & CScale Value & $\sum f_{j i} C$ & $M_{c}\left(R_{j}\right)$ & $\begin{array}{l}\text { Rank } \\
\text { Order }\end{array}$ \\
\hline 1 & $\begin{array}{l}\text { A comfortable life } \\
\text { (A Prosperous life) }\end{array}$ & 8 & 262 & 5.57 & 1 \\
\hline 2 & $\begin{array}{c}\text { An existing life } \\
\text { (A stimulating, active life) }\end{array}$ & 7 & 234 & 4.98 & 6 \\
\hline 3 & $\begin{array}{c}\text { A world at peace } \\
\text { (Free of war and conflict) }\end{array}$ & 7 & 219 & 4.66 & 12 \\
\hline 4 & Equality (Brotherhood, equal opportunity for all) & 6 & 231 & 4.91 & 8 \\
\hline 5 & $\begin{array}{c}\text { Family security } \\
\text { (Taking care of loved ones) }\end{array}$ & 6 & 223 & 4.74 & 11 \\
\hline 6 & $\begin{array}{c}\text { Freedom } \\
\text { (Independence, free choice) }\end{array}$ & 5 & 235 & 5.00 & 5 \\
\hline 7 & $\begin{array}{c}\text { Happiness } \\
\text { (Contentedness) }\end{array}$ & 5 & 232 & 4.94 & 7 \\
\hline 8 & $\begin{array}{c}\text { Pleasure } \\
\text { (An enjoyable, leisurely life) }\end{array}$ & 4 & 241 & 5.13 & 3 \\
\hline 9 & $\begin{array}{c}\text { Self respect } \\
(\text { Self esteem })\end{array}$ & 4 & 228 & 4.85 & 10 \\
\hline 10 & $\begin{array}{l}\text { Social Recognition } \\
\text { (Respect, admiration) }\end{array}$ & 3 & 230 & 4.89 & 9 \\
\hline 11 & $\begin{array}{c}\text { True Friendship } \\
\text { (Close companionship) }\end{array}$ & 3 & 248 & 5.28 & 2 \\
\hline 12 & Wisdom ( A mature understanding of life) & 2 & 237 & 5.04 & 4 \\
\hline
\end{tabular}

$\sum \mathrm{f}_{\mathrm{ji}} \mathrm{C}-$ Sum of the product of total preferences and $\mathrm{C}$ values

$\mathrm{M}_{\mathrm{c}}-$ Mean

$\mathrm{R}_{\mathrm{j}}-$ Response Value

\section{Appendix-2}

Table 2. Rank Orders of Instrumental Values of Tribal Future Teachers of B.Ed. Programme

\begin{tabular}{|c|c|c|c|c|c|}
\hline $\begin{array}{l}\text { Sl. } \\
\text { No. }\end{array}$ & Instrumental Values & CScale Value & $\sum f_{j i} C$ & $M_{c}\left(R_{j}\right)$ & $\begin{array}{l}\text { Rank } \\
\text { Order }\end{array}$ \\
\hline 1 & $\begin{array}{c}\text { Ambition } \\
\text { (Hard working, aspiring) }\end{array}$ & 8 & 230 & 4.89 & 9 \\
\hline 2 & $\begin{array}{c}\text { Broadminded } \\
(\text { Open minded })\end{array}$ & 7 & 234 & 4.98 & 7 \\
\hline 3 & $\begin{array}{c}\text { Capable } \\
\text { (Competent, effective) }\end{array}$ & 7 & 240 & 5.11 & 4 \\
\hline 4 & $\begin{array}{c}\text { Courageous } \\
\text { (Standing up for beliefs) }\end{array}$ & 6 & 214 & 4.55 & 12 \\
\hline 5 & $\begin{array}{c}\text { Forgiving } \\
\text { (Willing to pardon others) }\end{array}$ & 6 & 219 & 4.66 & 10 \\
\hline 6 & $\begin{array}{c}\text { Helpful } \\
\text { (Working for the welfare of others) }\end{array}$ & 5 & 236 & 5.02 & 6 \\
\hline 7 & $\begin{array}{c}\text { Honest } \\
\text { (Sincere, truthful) }\end{array}$ & 5 & 247 & 5.26 & 3 \\
\hline 8 & $\begin{array}{c}\text { Independent } \\
\text { (Self-reliant, self-sufficient) }\end{array}$ & 4 & 239 & 5.09 & 5 \\
\hline 9 & $\begin{array}{c}\text { Intellectual } \\
\text { (Intelligent, reflective) } \\
\end{array}$ & 4 & 219 & 4.66 & 11 \\
\hline 10 & $\begin{array}{c}\text { Obedient } \\
\text { (Dutiful, respectful) } \\
\end{array}$ & 3 & 254 & 5.40 & 2 \\
\hline 11 & $\begin{array}{c}\text { Polite } \\
\text { (Courteous, well-mannered) }\end{array}$ & 3 & 257 & 5.47 & 1 \\
\hline 12 & $\begin{array}{c}\text { Responsible } \\
\text { (Dependable, reliable) }\end{array}$ & 2 & 231 & 4.91 & 8 \\
\hline
\end{tabular}

$\sum \mathrm{f}_{\mathrm{ji}} \mathrm{C}-$ Sum of the product of total preferences and $\mathrm{C}$ values

$\mathrm{M}_{\mathrm{c}}-$ Mean

$\mathrm{R}_{\mathrm{j}}$ - Response Value 


\section{Appendix-3}

Table 3.Preferences of Terminal and Instrumental Values of Tribal Future Teachers of B.Ed. Programme

\begin{tabular}{|c|c|c|}
\hline \multicolumn{2}{|r|}{ More Preferred Terminal Values } & Less Preferred Terminal Values \\
\hline 1. & A comfortable life(A Prosperous life) & A world at peace(Free of war and conflict) \\
\hline 2. & True Friendship (Close companionship) & Family security(Taking care of loved ones) \\
\hline 3. & Pleasure(An enjoyable, leisurely life) & Self respect( Self esteem) \\
\hline \multicolumn{2}{|r|}{ More Preferred Instrumental Values } & Less Preferred Instrumental Values \\
\hline 1. & Polite(Courteous, well-mannered) & Courageous(Standing up for beliefs) \\
\hline 2. & Obedient(Dutiful, respectful) & Intellectual(Intelligent, reflective) \\
\hline 3. & Honest (Sincere, truthful) & Forgiving(Willing to pardon others) \\
\hline
\end{tabular}

\section{REFERENCES}

[1] Unesco. (2002). Educational Innovations and information. International Bureau of Education (IEE), Geneva, Switzerland. 1-5.

[2] NCERT. (1997). Fifth Survey of Educational Research (Vol. I). New Delhi.

[3] NCERT. (2000). Fifth Survey of Educational Research (Vol.II). New Delhi.

[4] NCERT. (2007). Sixth Survey of Educational Research (Vol. II). New Delhi.

[5] Parliament of India. (1999). Eighty First Report on Value-based Education. Rajya Sabha Secretariat, New Delhi.

[6] Longstreth, L.E. (1979). Values in the Social Studies: Implicit, Explicit or Ignored, Social Education. In S.P. Kulshrestha (Ed.). Emerging value-pattern of Teachers and New Trends of Education in India, Light and Life Publishers. New Delhi, 39.

[7] Kakkar, S.B. (1992). Readings in Educational Psychology. Atlantic Publishers \& Distributors. Online available from http://books.google.co.in/books?id=MTvEozt SOtcC

[8] Usha Sri, V. (1995). Restructuring Teacher Education for Value Orientation. Journal of Higher Education. 16(4), 601-649.

[9] Singh, L.C. and Singh Prabhakar. (1986). Effectiveness of Value Clarification Strategies in Value Orientation of B.Ed. students. Report of ERIC Foundation Research Project. NCERT. New Delhi.

[10] Winterbottom, M. Tabler. (2008). Understanding differences in trainee teachers' values and Practice in Relation to Assessment. Teacher Development, 12(3). 15-35.

[11] Bhushan, A. (1979). Values across Sex and Family Vocations, School of Education, Himachal Pradesh University. In Buch, M. B. (Ed.). Third Survey of Research in Education, 1987, NCERT, New Delhi, 113.

[12] Nayyar, Surinder Mohan. (1989). Closed Mindedness, Open Mindedness and Teacher Values of Student-teachers in Relation to Caste and Class. Indian Educational Review, 24(1), 157-169.

[13] Singh, L.C. (1989). Effectiveness of Values Clarifying Strategies in Value Orientation of B.Ed. Students. Fifth Survey of Research Educational Research (Vol. II), 2000, NCERT, New Delhi, 1351.

[14] Rajendra Prasad, D. (2008). Value Orientation among Male and Female B.Ed. Teacher Trainees of IGNOU. New Frontiers in Education, 41(4), 431-439.

[15] Rajendra Prasad, D. (2008). Value Preferences and Value System among M.Ed. Students. Journal of Indian Education, 33(4), 17-24.

[16] Escobar, Ortloff, L. M. and Ortloff, W, G. (2000). Differences in Social and Moral Hierarchical Values among American Preservice teachers and Professors. Paper presented in the Annual Meeting of the Society for the Philosophy and History of Education. September 30. Biloxi, MS.

[17] Mitra, Aparna. (2008). The Status of Women among the Scheduled Tribes in India. Journal of Socio-Economics, 37 (3), 1202-1217.

[18] Locke, Steven and Lindley, Lorinda. (2007). Rethinking Social Studies for a Critical Democracy in American Indian/Alaska Native. Journal of American Indian Education, 46 (1). 1-19. Online available from http://eric.ed.gov/?id=EJ 784821 .

[19] Zheng, H. (2009). A Review of Research on EFL Pre-Service Teachers' Beliefs and Practices. Journal of Cambridge Studies, 4(1), 80. 